\title{
The Role of Integrated Marketing Communications in Increasing the Efficiency of Internet-based Marketing among Jordanian Consumers
}

\author{
Nafez Nimer Hasan Ali $^{1} \&$ Mahmoud Allan ${ }^{1}$ \\ ${ }^{1}$ Marketing Department, Faculty of Business, Al-Zaytoona University of Jordan, Amman, Jordan \\ Correspondence: Nafez Nimer Hasan Ali, Marketing Department, Faculty of Business, Al-Zaytoona University \\ of Jordan, Amman, Jordan. E-mail: N.Ali@zuj.edu.jo or Allan@zuj.edu.jo
}

Received: June 22, 2017 Accepted: July 10, 2017 Online Published: July 28, 2017

doi:10.5539/ijms.v9n4p97 URL: http://doi.org/10.5539/ijms.v9n4p97

\begin{abstract}
Many marketing strategies including and approaches like CRM, mass marketing, PR marketing and IMC have developed for the sake of increasing the demand on the product and elevate the level of customer satisfaction. With the technological development and the entrance of internet marketing there appeared an urgent need to increase the intensity of the marketing strategies in a way that matches the concept of online marketing as distance marketing. From that point, the current study seeks to understand the influence of integrated marketing communication (IMC) on the efficiency of internet-based marketing from the perspective of Jordanian customers. The variables which are employed in the current study are (communicational messaging, direct marketing, online marketing, promotion, mass media marketing and public relations). The sample of the study consisted of (349) customer from malls, commercial complexes and trading center. Through the quantitative approach and utilizing the questionnaire; the results of the study indicated there is a positive influence of IMC on the internet-based marketing within the variables of (communicational messaging, direct marketing, public relations, and mass media marketing) while (promotions and online marketing) seemed to have no influence on the internet-based marketing. The study recommends carrying out a research study that examines the influence of E-IMC on the online marketing practices through social media websites.
\end{abstract}

Keywords: Integrated Marketing Communication, social media marketing platforms, internet-based marketing, direct marketing

\section{Introduction}

Marketing is considered to be one of the most important activities that organizations do through their operating time. However, and within the course of time, there appeared the technological booming which changed the way organizations operate, market their products/services and contact with their clients.

Within the field of marketing, there is no doubt for sure that the organization must be aware of what is the best way to approach their clients and build strong relationships with them in order to increase their retention and at the same time increase the market value of the organization. Based on that, researcher and scholars have located the best way to reach the maximum level of communication with the clients; the basic structure of that choice is in communication. With the technological booming which took place in many aspects of life communication appeared to have more than one single way; it can be done through the internet and other communication medium. The idea of building communication can be achieved through creating a state of harmony between the technological communicational channels along with the traditional communicational tools which would lead to harmony and synchronization in communicating with clients (Grönroos, 2004).

The idea of harmonizing the communication channels between technological and traditional have transformed today into a new concept. This concept generates from the customer relationship management (CRM) which have led to the creation of the integrated marketing communication (IMC) (Winter \& Sundqvist, 2009). The idea of IMC has emerged as an approach that emphasizes on the need to connect and link all the communication means together in harmony in order to guarantee their operating in the most efficient way. When applying this concept on the internet marketing, one can develop an idea in their head articulated that the role of IMC appear in the internet marketing as a way to connect and link all the organization's accounts on the marketing websites in a way that one addresses the other and transports the feedback directly to the concerned party. 


\section{Importance of the Study}

Based on the above argument, technology has become an important factor that pushes business forward. Everything in our lives today can be managed through the means of internet, it included medicine, education, banking and governmental transactions. In the marketing world, the concept of technology is very important as it facilitated the communication platform between the producer and the end user. In addition to that, it helped in providing communication means with the least cost and best profits. The concept of integrated marketing communication is an important theory in the marketing field. Integrated marketing communication or the so called-IMC - was defined by Hawkins, Bulmer, \& Eagle (2011, p. 5) defined IMC as "the planning and execution of all types of advertising-like and promotion-like messages selected for a brand, service, or company, in order to meet a common set of communication objectives, or more particularly, to support a single positioning". But, when going through this theory or concept, one may ask how this concept can influence the efficiency of the online marketing field, or the internet-based marketing? The current research seeks to understand the relationship between IMC and the internet-based marketing and how IMC can influence the online marketing within the current wave of the technological development.

\section{Literature Review}

\subsection{Introduction}

According to the study by Elena \& Oancea (2015) in which the authors have focused on the dimensions of the IMC, it included the variables of (Communicational Message, Mass Media Advertising, Promotions, Direct Marketing, Public Relations, and Online Marketing). The author has chosen those variables to be applied in the current research study and understand their influence on the efficiency of internet-based marketing. From another perspective, (Al Khattab, Abu-Rumman, \& Zaidan, 2015) gathered between the concepts of IMC and the idea of online marketing referring to the fact that integrated marketing communication play a role in increasing the efficiency of the marketing plans and strategies; and sense the online marketing is considered to be a marketing plan and strategy then it must be influence by the IMC practices within the organization and that is what this study seeks to understand.

So, launching from the previous studies the current study claims that "There is a statistically significant influence of IMC on the efficiency of internet-based marketing". This claim was connected along with the variables of the study which included (Communicational Message, Mass Media Advertising, promotions, direct marketing, public relations and online marketing). Part of those variables was used in a study by Elena \& Oancea (2015) while the others appeared in different studies including (Al Khattab, Abu-Rumman, \& Zaidan, 2015). Both dependent and independent variables of the study appeared in their final version as the following:

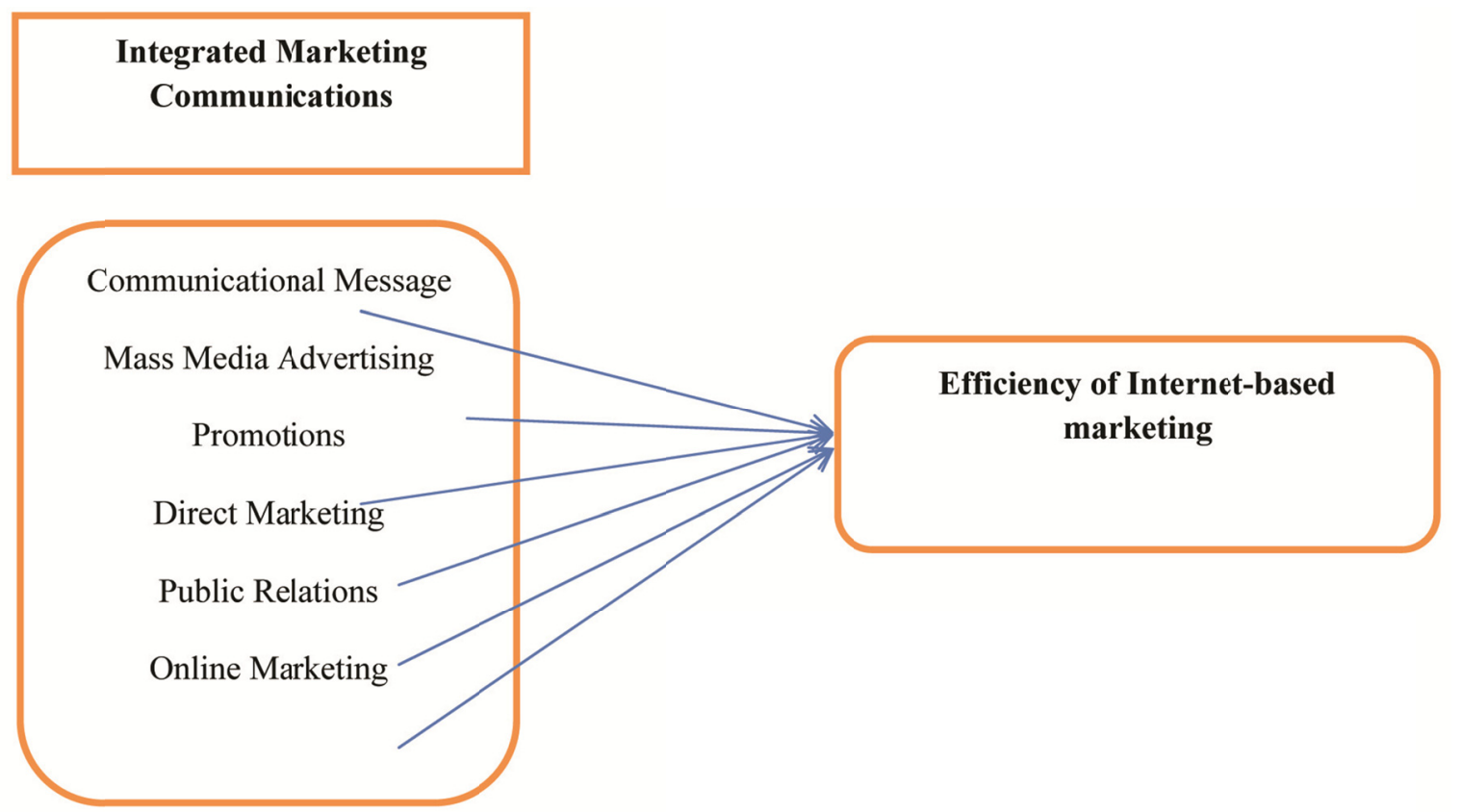

Figure 1. Study model (Elena \& Oancea, 2015) 


\subsection{The Emergence of Internet-Based Marketing}

Conventional marketing depends on choices in four fundamental controllable classifications marked the four "P's": Product, Price, Place and Promotion. In this marketing scheme the "item" is a physical thing or administration where the brand and its qualities are the head contemplation. Cost requires aggressive investigation and a cost procedure to enter a market. Put more often than not alludes to the dissemination channel where the item is conveyed, requested and warehoused. This leaves advancement the part of imparting the advantage, require, charm, claim and passionate association of the item or administration to the customer.

According to Sharma, Singh, \& Sharma (2015) internet-based marketing is the way toward advancing an association utilizing on the web media, normally with the objectives of expanding deals and boosting income. Internet-based marketing does not just mean building or advancing a site nor does it mean basically putting a flag promotion up on another Web website. Successful internet-based marketing requires an exhaustive technique that synergizes a given organization's plan of action and deals runs with their webpage capacity and appearance, concentrating on their objective market through legitimate decision of promoting sort, media, and plan.

Internet-based marketing stands for the activity of marketing for an item/product through the means of the internet; it relates to exchanging products and ventures through the electronic medium. The utilization of web based business has been developing, making new open doors for business magnate to enhance current methods for working together and affecting the advancement of aggressive advertising technique (Sheth \& Sharma, 2005).

The word "marketing" has two particular implications as far as present day administration hone. It depicts the scope of master advertising capacities done inside associations. Such capacities incorporate statistical surveying, mark/item administration, advertising, client benefit and so forth and an approach or idea that can be utilized as a directing theory for all capacities and exercises of an association.

According to Wilson \& Laskey (2003) such logic incorporates all parts of a business. Business procedure is guided by an association's market and rival center and everybody in an association ought to be required to have a client center in their employment. The present day showcasing idea joins these two implications and stresses that promoting includes the scope of hierarchical capacities and procedures that try to decide the requirements of target markets and convey items and administrations to clients and different partners, for example, representatives and money related foundations. Progressively the significance of advertising is being perceived both as a key capacity and as controlling administration rationality inside associations (Hamill, 1997).

Holm (2006) draw out that there is an open door for Internet advertising astigmatism. Web promoting is regularly drawn closer as a correspondence and offering apparatus. On the off chance that Internet promoting is to end up noticeably coordinated and completely settled as a vital advertising administration instrument, the concentration needs to move towards understanding its more extensive applications inside the aggregate showcasing process as opposed to simply utilizing ist for correspondence and offering (Pitta \& Fowler, 2005). The utilization of Internet has noteworthy ramifications for the route in which associations with channel accomplices, for example, wholesalers, merchants and retailers are overseen. Extranets are regularly used to deal with these linkages electronically. Web can cause disinter-intervention and reinter-intercession (Furrer \& Sudharshan, 2001).

\subsection{Multimedia Marketing}

Integrated Marketing Communication (IMC) stresses the advantages of tackling collaboration over different media to fabricate mark value of items and administrations. Present day promoting reading material receive the IMC point of view, real colleges offer IMC courses and numerous advertisers and publicizing organizations grasp the idea (Finne \& Grönroos, 2017). The American Association of Advertising Agencies characterizes IMC as takes after: An idea of showcasing interchanges arranging that perceives the additional estimation of [a] far reaching arrangement that assesses the key parts of an assortment of correspondence orders - for instance, (Porcu, Del Barrio-García, \& Kitchen, 2017) general publicizing, coordinate reaction, deals advancement, and advertising - and joins these orders to give clearness, consistency, and most extreme interchanges affect.

This definition perceives the additional esteem part of IMC, which is made by the joint effect of different activities (e.g., TV and print promoting). At the end of the day, the joined impact of numerous exercises surpasses the whole of their individual impacts; this wonder is known as cooperative energy (Grove, Carlson, \& Dorsch, 2002). 


\subsection{Integrated Marketing Communications (IMC)}

Schultz (1993) defined IMC as "a concept of marketing communication planning that combine and evaluate strategic role of different communication discipline to get the clarity, consistency and greater impact" (Naeem, Bilal, \& Naz, 2013, p. 124). In the early years of IMC considering, in spite of the sentiments of many promoting directors that publicizing offices might not have been the best arranging impetus for IMC, they played a noteworthy part in giving and dealing with these underlying endeavors at coordinating advertising correspondences. Various expansive publicizing offices and office gatherings were very dynamic in this new range of IMC. Significant organizations attempted to manage this issue in various ways (Kitchen, 2005). Numerous organizations set up projects to teach their administrators in IMCs. Before its separation in 1995, Lintas Campbell-Ewald, a division of The Interpublic Group of Companies, had for quite a long while offered a broad preparing program in IMCs for their center and upper level administrators. Leo Burnett, one of the early pioneers in the IMCs field, executed another incorporated arranging and correspondences program. Their objective was for the majority of the Burnett then 2000 or more US workers to go to the 6-day classes. Real publicizing offices may have become off to a moderate or even wrong begin; however there is doubtlessly they appeared to be focused on (Henninger, Alevizou, \& Oates, 2017).

\subsection{Communicational Message}

It is ordinary for Communications messages to concentrate on the advantages that a brand gives to its clients and therefore pulls in their consideration, fortifies premium and supports basic leadership and thus - the buy of the brand. By utilizing Marketing Communications associations seek after fundamentally financial objectives and keeping in mind the end goal to accomplish them, firms spend aggregates that, now and again, are huge. Present day showcasing requires something beyond building up a decent item, its alluring valuation and furnishing customers with access to it. Organizations additionally need to stay in contact with both present and potential customers. Each organization unavoidably assumes the part of imparting and advancing means (Finne \& Grönroos, 2017).

The hypothetical establishments of interchanges are the reason for the creation and improvement of the idea of Integrated Marketing Communications. Globalization and new advances are among the most significant explanations behind the adjustment in the method for organizations and their clients impart (Grönroos, 2004). Changes in the market economy, and in addition in the primary attributes of the business sectors, likewise add to the improvement of IMC. One of these progressions, which merits an uncommon consideration is the detachment of mass markets into numerous scaled down business sectors, each of which requires its own correspondence approach. Moreover, new media are creating and purchasers' insight and mindfulness is continually developing. Every one of these progressions are constraining organizations to look for a more entire and more present day utilization of the correspondence approach. This inescapable prompts the creation and execution of the Integrated Marketing Communications in the act of various business associations (Valos et al., 2016).

\subsection{Mass Media Advertising}

According to Littler (2015), Mass media is defined as "impersonal channels by which the communicator can communicate directly with the target audience" (p. 1). In another meaning, mass media refers to the large platforms on the internet which gathers different individuals from different geographical places who share the same interest in an item/product or a service. The idea of mass media including (television, radio, print media, and the Internet) facilitates the process of reaching the targeted audience with the least efforts needed. In the social world the mass media is more like the social networks on which the organization builds a virtual store (online shop, page) and opens the channels for individuals to communicate with them through these means in order to take information, purchase stuff or even complain about a certain malfunction in the service.

\subsection{Promotions}

Huang et al. (2014) defined promotions as the process of bringing the product/service or item to the attention of the customer in a way that influences their attitude towards this item. This process can be done in different approaches including the prices, packaging, developing and/or quality enhancement. The idea of promotions has been for a long time the main and most attractive factor among customer. Normally when someone wants to buy something they look for places which are carrying promotions for the item they want to buy, they are usually influenced by the fact that they bought a certain item on promotion or during the promotion season.

Cowell (1984) argued that the idea of promotions has been helpful in a number of ways. He said that promotions can attract potential customers and retain the existed customers; it can guarantee the reaching of the target in the 
organization specially if the promotional scheme is taking place on the price and value, and promotions can help in presenting more sponsors and activities in the social platform.

\subsection{Direct Marketing}

Direct marketing comprises of promoting interchanges that utilization coordinate media advances, for example, regular postal mail and print catalogs. Intelligent advertising is an expansion of direct marketing into media advances that permit two-route interchanges between a purchaser and a vender. Cases of intuitive promoting are email, online advertisements that can be navigated, and internet business sites. The benefits of immediate and intelligent advertising incorporate the capacity to unequivocally impart to people with addressable messages that can be redone in ways that make messages more applicable to purchasers (Mallin \& Finkle, 2007).

Immediate and intuitive showcasing strategies ordinarily incorporate a reaction system that enables buyers to react specifically to a correspondence and conceivably make a buy. Contrasted with broad communications interchanges, immediate and intelligent advertising is considerably more exact and quantifiable (Akhter, 1988). The capacity to gauge immediate and intuitive promoting impacts enables advertisers to outline correspondence programs that objective customers in light of the measure of time since last buy, recurrence - the quantity of past buys, and fiscal esteem - the aggregate uses a client sets aside a few minutes (Korgaonkar, Karson, \& Lund, 2000). The techniques, strategies, and measurements of immediate and intuitive showcasing are ending up noticeably more integral to advertising procedure as advanced innovations enable intelligent promoting interchanges to happen through TV and cell phones (Hauser, 2008).

\subsection{Public Relations}

Public relations are something that should occur for small to zero cost. Public relations generally include realizing an adjustment in mentality or familiarity with an association, with any subsequent Publicity as the result (Quesinberry Stokes, 2009). Raising the Profile of an association is a Public Relations work. Advertising includes many practices and methods used to assemble affinity and comprehension with an association's intended interest groups (Kitchen, 1993). In its broadest sense it is the interface between gatherings in the public arena. The Public Relations Institute of New Zealand characterizes advertising as: "the deliberate, arranged and managed push to set up and keep up shared comprehension between an association and its open" (Khoo-Lattimore, 2012).

Public relations is something other than exposure - or free scope-and in certainty incorporates various exercises which are some of the time lumped together and called "correspondences" (Neuhaus \& Snowden, 2003). These incorporate media relations, raising money, enrollment drives and unique occasion administration. In this asset we will concentrate on media relations and leave raising support, uncommon occasion administration (counting sponsorship) as subjects for different assets (Gürel \& Kavak, 2010).

\subsection{IMC and Customer Behavior}

According to Al Khattab, Abu-Rumman, \& Zaidan (2015) the quick pace of progress in marketing communications has significantly impacted clients' conduct in general and particularly clients' dispositions toward items in this developing intelligent market space. In rundown, this exploration worried about the effect of utilizing E-IMC on clients' states of mind toward electronic items in Jordan, revealing insight into online trust as a direct factor. Understanding clients' reactions to such developing computerized multi-correspondence multi-channel and multi-classification condition helps firms in detailing better behavioral focusing on techniques; that are to connect clients in light of where they are found and what their interests are.

On the other hand, Naeem, Bilal, \& Naz (2013) argued that this dynamic research sees how developing media can increase customary media. This is amazingly basic for better administration of client connections and advancement of systems that go for a viable assignment of planned limited time dollars through its dynamic effect on clients' states of mind, buy frequency and amount choices. Incorporated Marketing Communication (IMC) has gotten practically moment acknowledgment by the mid of the 1990s. The elements that principally between played prompting such raising acknowledgment were cost decrease separated from mass customary promoting into a more customized correspondence.

Bruhn \& Schnebelen (2017) added that reasons are fracture of media, clients and web notwithstanding versatile advancements giving the upside of a more incorporated administration and also corporate message consistency. Every past element utilized this method of correspondence not exclusively to develop a more profound security with clients and influencers additionally to boost degree of profitability (ROI) by incorporating conventional advertising interchanges with E-IMC next to each other (Hawkins, Bulmer, \& Eagle, 2011). 


\subsection{Efficiency of Internet-Based Marketing}

It is a well-known fact that the field of marketing has undergone many substantial changes and most of these changes are attributed to the emergence of internet and the World Wide Web. Internet-based marketing has played a huge role in increasing the efficiency of the marketing plans and strategies through its ability to reach different places at the same time, in other meaning, it is known that internet-based marketing is not bounded to a certain geographical place and time, so, it has the ability to reach the needed audience regardless of their residence and time (Hamill, 1997).

Based on that, among the most importance advantages of internet-based marketing is that is has the ability to dissolve the geographical barriers which enables the marketing strategies and makes it more efficient. Also, it was argued by (Bandyopadhyay, 2001) that the efficiency of internet-based marketing is derived from that fact that it has the ability to target the needed audience with less efforts and costs compared to the conventional marketing approaches, which means more clients and potential customers in less time (Sloka, Kantane, \& Vidruska, 2016).

On the other hand, (Paul, 1996; Pitta \& Fowler, 2005) found out that efficiency of the intent-based marketing is derived from its ability to empower the organization which is promoting for its service/product. This empowerment comes from the nature of the chances that are given to the organization launching from choosing the target, framing the audience and shaping the nature of the marketing discourse. (Wilson \& Laskey, 2003) saw that the efficiency of the internet-based marketing is attributed to its ability to mark out the flaws and gaps in marketing plan from one side, in addition to that, it can deliver any faults or complains to the responsible party in less time compared to the conventional approach; not to mention its efficiency in delivering immediate results in regard to the response rate from the customers and the followed marketing strategies of the competitors.

On the same track, (Wong, Chan, \& Leung, 2005) saw that one of the advantages that increases the efficiency of the internet-based marketing is the fact that it can be 'personalized', in another meaning, the organization has the ability to draw its personality within the marketing strategies and plans within the campaigns that are being carried out which gives a sense of intimacy between the organization and the client (Weiber \& Kollmann, 1998).

\section{Methodology}

\subsection{Research Design}

The researcher in the current research study utilized the quantitative approach to be the main research design. The quantitative approach is basically built on the idea of gathering numerical data which are utilized through the SPSS and translated into words that may uncover the actual stand points of the participating sample in regard of the study.

\subsection{Research Tool}

As a tool, the researcher has chosen the self-administered questionnaire in order to be the tool of the study, the questionnaire was distributed on the sample of the study and it contained questions regarding the issue under examination. The questionnaire was built by the author through utilizing ideas and notes from different previous articles and studies.

\subsection{Research Sample}

The sample of the study refers to individuals who are willing to take part in a certain scientific (academic) research through giving their point of view (opinion) in regard to a certain idea (theory/generalization).

The sample of the current research study was a convenient sample in which individuals were chosen to from the participating members in the study. The population of the sample consisted of individuals (citizens) from different malls, commercial complexes and markets in Jordan. The researcher distributed total of (400) questionnaires on a convenient sample of individuals within the markets and malls in Jordan, Amman. After the collection of the questionnaire and the refining and polishing process, the researcher was able to retrieve (349) properly filled questionnaires which were eligible for the statistical analysis. It is worth to mention here that the response rate was $\mathbf{8 7 . 2 5 \%}$ of the total sample which seen to be a very good rate to the analysis and results of the study.

\subsection{Statistical Processing}

The data of the current research will be processed using the Statistical Package of Social Research SPSS/ V. 22.0. The following statistical processes will take place on the data collected:

- Descriptive analysis 
- $\quad$ Multiple Regression

- $\quad$ Reliability Test

- VIF test

\subsection{Operational Definitions}

Integrated Marketing Communication: Refers to "a management concept which is designed to make unified force of different aspects of marketing communication such as sales promotion, public relations, advertising and direct marketing rather than to work in isolation" (Saeed et al., 2013)

Communicational messaging: Refers to the process of transmitting messages between a sender and a receiver in a marketing medium.

Direct marketing: "The communication (by whatever means) of any advertising marketing material which is directed to particular individuals" (Bird \& Bird, 2004); (Schofield, 1995)

Online marketing: refers to the process if using the internet means for carrying out makreting activities and plans

Promotion: Refers to the "marketing activities, other than personal selling, advertising, and publicity, that stimulate consumer purchasing and dealer effectiveness, such as displays, shows and exhibitions, demonstrations, and various non-recurrent selling efforts not in the ordinary routine." (Burnett, 2012)

Mass media marketing: Refers to the "application of commercial marketing technologies to the analysis, planning, execution, and evaluation of programs designed to influence the voluntary behavior of target audiences in order to improve their personal welfare and that of their society" (Beltsville, 2004)

Public relations: Refers to a "distinctive management function which helps establish and maintain mutual lines of communication, understanding, acceptance, and cooperation between an organization and its publics" (Harlow, 2013)

\subsection{Validity Test}

The tool of the study (questionnaire) was designed by the author based on the previous studies which were available. After the completion of the questionnaire, it was presented in front of a group of professors and specialists in the field on marketing. Based on that, the researcher modified the questionnaire according to the notes of the reviewers and before it was distributed on the sample of the study for the application process.

\section{Results}

The following section represents the statistical results of the gathered data from the questionnaires. The section is divided into two parts. The first part takes into consideration the demographic variables of the study, while the second part presents the analysis of the questionnaire paragraphs according to the answers of the sample of the study.

\subsection{Demographic Variables}

Table 1. Sample characteristics according to gender

\begin{tabular}{llllll}
\hline & & Frequency & Percent & Valid Percent & Cumulative Percent \\
\hline Valid & Male & 186 & 53.3 & 53.3 & 53.3 \\
& Female & 163 & 46.7 & 46.7 & 100.0 \\
& Total & 349 & 100.0 & 100.0 & \\
\hline
\end{tabular}

According to table (1), most of the sample appeared to be males with a percentage of $53.3 \%$ of the total compared to females with a percentage of $46.7 \%$. This indicates that males formed the majority of the sample which answered the questionnaire.

Table 2. Sample characteristics according to educational level

\begin{tabular}{llllll}
\hline & & Frequency & Percent & Valid Percent & Cumulative Percent \\
\hline Valid & High School & 70 & 20.1 & 20.1 & 20.1 \\
& Bachelor & 187 & 53.6 & 53.6 & 73.6 \\
& Post Graduate & 92 & 26.4 & 26.4 & 100.0 \\
Total & 349 & 100.0 & 100.0 & \\
\hline
\end{tabular}


Table (2) above shows that the majority of the sample which responded to the questionnaire were individuals who held the bachelor degree with a percentage of $53.6 \%$ while individuals with a postgraduate degree came in the second rank with a percentage of $26.4 \%$. The least percentage of individuals who had high school came with a percentage of $20.1 \%$ which indicates the level of education among Jordanian individuals.

Table 3. Sample characteristics according to age

\begin{tabular}{llllll}
\hline & & Frequency & Percent & Valid Percent & Cumulative Percent \\
\hline Valid & $18-23$ & 73 & 20.9 & 20.9 & 20.9 \\
& $24-29$ & 118 & 33.8 & 33.8 & 54.7 \\
& $30-35$ & 158 & 45.3 & 45.3 & 100.0 \\
& +36 & & & & \\
& Total & 349 & 100.0 & 100.0 & \\
\hline
\end{tabular}

The above table (3) indicated that individuals who answered the questionnaire of the study within the age range of 30-35 years formed the majority of the study with a percentage of $45.3 \%$. On the other hand, it appeared through the analysis that individuals within the age range of 24-29 years appeared to be in the second place with a percentage of $33.8 \%$. However, the least percentage came in favor of individuals with the age range of 18-23 with a percentage of $20.9 \%$ and none of the sample appeared to be above 36 years old. This indicates that the majority of the samples of the study were of the young age.

Table 4. Sample characteristics according to occupation

\begin{tabular}{llllll}
\hline & & Frequency & Percent & Valid Percent & Cumulative Percent \\
\hline Valid & Student & 72 & 20.6 & 20.6 & 20.6 \\
& Pubic Employee & 122 & 35.0 & 35.0 & 55.6 \\
& Private Employee & 129 & 37.0 & 37.0 & 92.6 \\
Self-Employed & 14 & 4.0 & 4.0 & 96.6 \\
& House Wife & 12 & 3.4 & 3.4 & 100.0 \\
Total & 349 & 100.0 & 100.0 & \\
\hline
\end{tabular}

The above table (4) indicated that individuals who answered the questionnaire of the study who worked within the private sector formed the majority of the study with a percentage of $37 \%$. On the other hand, it appeared through the analysis that individuals who worked within the public sector appeared to be in the second place with a percentage of $35 \%$. However, the least percentage came in favor of house wives with a percentage of $3.4 \%$.

\subsection{Questionnaire Paragraph}

Table 5. Descriptive statistics

\begin{tabular}{|c|c|c|c|c|c|}
\hline Paragraph & $\mathrm{N}$ & Minimum & Maximum & Mean & Std. Deviation \\
\hline \multicolumn{6}{|l|}{ Internet-Based Marketing } \\
\hline $\begin{array}{l}\text { Internet-based marketing uses various online advertisements to drive } \\
\text { traffic to an advertiser's website }\end{array}$ & 349 & 1.00 & 5.00 & 3.2464 & .93895 \\
\hline Internet-based marketing brings the most value to the advertiser & 349 & 2.00 & 4.00 & 3.3983 & 69406 \\
\hline Internet-based marketing revolutionized the way business is conducted & 349 & 2.00 & 4.00 & 3.1289 & .76789 \\
\hline $\begin{array}{l}\text { Internet-based marketing enables organizations to obtain several } \\
\text { competitive advantages over the competition }\end{array}$ & 349 & 2.00 & 4.00 & 3.3639 & .65387 \\
\hline $\begin{array}{l}\text { Internet-based marketing has reduced the cost of producing and } \\
\text { distributing digital goods }\end{array}$ & 349 & 2.00 & 5.00 & 3.3725 & .62876 \\
\hline \multicolumn{6}{|l|}{ Communicational Messages } \\
\hline The communication message play a role in the brand building & 349 & 2.00 & 5.00 & 3.5129 & .71758 \\
\hline Communicational messages mean communication with the customer & 349 & 2.00 & 5.00 & 3.5272 & .68016 \\
\hline Communicational messages can influence the customer behavior & 349 & 2.00 & 5.00 & 3.5158 & .76407 \\
\hline It is important to communicate through verbal messages & 349 & 2.00 & 5.00 & 3.6734 & .76332 \\
\hline
\end{tabular}




\begin{tabular}{|c|c|c|c|c|c|}
\hline \multicolumn{6}{|l|}{ Mass Media Advertising } \\
\hline Mass media is a good approach to target audience & 349 & 2.00 & 5.00 & 3.8424 & .87483 \\
\hline $\begin{array}{l}\text { Advertising through mass media shows how developed the } \\
\text { organization is }\end{array}$ & 349 & 2.00 & 5.00 & 3.6734 & .63146 \\
\hline Mass media advertising is less in cost & 349 & 2.00 & 5.00 & 3.5960 & .73897 \\
\hline Mass media advertising is cost effective & 349 & 3.00 & 4.00 & 3.4585 & .49899 \\
\hline Mass media advertising is time effective & 349 & 2.00 & 5.00 & 3.7249 & .77607 \\
\hline \multicolumn{6}{|l|}{ Promotions } \\
\hline Promotions attracts the attention of customers & 349 & 2.00 & 5.00 & 3.3696 & .63725 \\
\hline Promotions shows how the organization cares about its clients & 349 & 2.00 & 4.00 & 3.3954 & .56587 \\
\hline It is much easier to attract customers through promotions & 349 & 2.00 & 5.00 & 3.3582 & .78093 \\
\hline Customers are always attracted to promotions & 349 & 2.00 & 5.00 & 3.1662 & .94133 \\
\hline Promotions are a good approach to make profit in lee time & 349 & 1.00 & 5.00 & 3.0745 & 1.10128 \\
\hline \multicolumn{6}{|l|}{ Direct Marketing } \\
\hline Direct messaging guarantees more customers & 349 & 2.00 & 4.00 & 3.3754 & .60131 \\
\hline Direct messaging guarantees more potential customers & 349 & 2.00 & 4.00 & 3.2722 & .82200 \\
\hline It can be said that direct messaging is a waste of time & 349 & 2.00 & 4.00 & 3.0774 & .61800 \\
\hline Direct marketing is a good approach to locate unsatisfied customers & 349 & 2.00 & 4.00 & 3.2321 & .66133 \\
\hline \multicolumn{6}{|l|}{ Public Relations } \\
\hline Public relations guarantees satisfied customers & 349 & 2.00 & 4.00 & 3.1691 & .69693 \\
\hline Public relations attracts potential customers & 349 & 2.00 & 5.00 & 3.9628 & .87513 \\
\hline It is important for the organization to build its public relations & 349 & 3.00 & 5.00 & 4.1461 & .55072 \\
\hline Public relations are a cost effective marketing approach & 349 & 2.00 & 5.00 & 3.9083 & .89228 \\
\hline \multicolumn{6}{|l|}{ Online Marketing } \\
\hline Online marketing is a cost effective marketing plan & 349 & 2.00 & 5.00 & 3.9226 & .93911 \\
\hline $\begin{array}{l}\text { It is important for the organization to carry on with the online } \\
\text { marketing }\end{array}$ & 349 & 2.00 & 5.00 & 4.1920 & .91936 \\
\hline People are more convinced with the online marketing & 349 & 3.00 & 5.00 & 4.3066 & .91318 \\
\hline Online marketing attracts potential customers & 349 & 3.00 & 5.00 & 4.3095 & .91063 \\
\hline
\end{tabular}

Table (5) shows the mean and standard deviations of the individuals' responses to the questionnaire paragraphs. The results in the table indicate that there are positive attitudes toward the questions of the study as per each variable because their means are above the mean of the scale (3). This shows that individuals had the needed understanding of the concepts under examination, in addition to that their responses were positive to the hypotheses of the study which seen to be a good indicator.

\subsection{Reliability Test}

A Cronbach Alpha test has been used to ascertain instrument reliability. The value has been $=0.953$ for the questionnaire. All values are accepted since they are more than 0.60 .

Table 6. Descriptive statistics

\begin{tabular}{llllll}
\hline & $\mathrm{N}$ & Minimum & Maximum & Mean & Std. Deviation \\
\hline Communicational Message & 349 & 2.50 & 5.00 & 3.5573 & .62279 \\
Mass media Advertising & 349 & 2.60 & 4.60 & 3.6590 & .56310 \\
Promotions & 349 & 2.40 & 4.20 & 3.2728 & .57463 \\
Direct Marketing & 349 & 2.25 & 4.00 & 3.2393 & .51283 \\
Public Relations & 349 & 2.75 & 4.75 & 3.7966 & .52332 \\
Online Marketing & 349 & 2.50 & 5.00 & 4.1827 & .84489 \\
Internet-based Marketing & 349 & 2.40 & 4.20 & 3.3020 & .51497 \\
Valid N (listwise) & 349 & & & & \\
\hline
\end{tabular}

Table (6) above indicates that there are positive attitudes toward above variables because their means are above the mean of the scale (3). Apparently the variable of online marketing appeared to be the most variable which the respondents interacted to since its mean appeared to be higher than other variables (mean=4.1827). 


\subsection{Hypotheses Testing}

The following tables present the testing of the hypotheses of the study, the main hypothesis was "There is a statistically significant influence of IMC on the efficiency of internet-based marketing", while the sub-hypotheses appeared as follows:

$\mathbf{H}_{1}$ : There is a statistically significant influence of Communicational Message on the efficiency of internet-based marketing.

$\mathbf{H}_{2}$ : There is a statistically significant influence of Mass Media Advertising on the efficiency of internet-based marketing.

$\mathbf{H}_{3}$ : There is a statistically significant influence of promotions on the efficiency of internet-based marketing.

$\mathbf{H}_{\mathbf{4}}$ : There is a statistically significant influence of direct marketing on the efficiency of internet-based marketing.

$\mathbf{H}_{5}$ : There is a statistically significant influence of public relations on the efficiency of internet-based marketing.

$\mathbf{H}_{6}$ : There is a statistically significant influence of online marketing on the efficiency of internet-based marketing.

Table 7. Model summary

\begin{tabular}{lllll}
\hline Model & R & R Square & Adjusted R Square & Std. Error of the Estimate \\
\hline 1 & $.845^{\mathrm{a}}$ & .713 & .708 & .27812 \\
\hline
\end{tabular}

Table 8. ANOVA ${ }^{\mathrm{a}}$

\begin{tabular}{|c|c|c|c|c|c|c|}
\hline \multicolumn{2}{|c|}{ Model } & Sum of Squares & df & Mean Square & $\mathrm{F}$ & Sig. \\
\hline 1 & Regression & 65.835 & 6 & 10.972 & 141.853 & $.000^{\mathrm{b}}$ \\
\hline & Residual & 26.454 & 342 & .077 & & \\
\hline & Total & 92.289 & 348 & & & \\
\hline
\end{tabular}

Table 9. Coefficients ${ }^{\mathrm{a}}$

\begin{tabular}{lllllll}
\hline Model & & \multicolumn{2}{l}{ Unstandardized Coefficients } & Standardized Coefficients & $\mathrm{t}$ & Sig. \\
& & $\mathrm{B}$ & Std. Error & Beta & & \\
\hline 1 & (Constant) & -.092 & .128 & & -.721 & .471 \\
& Communicational Message & -.188 & .045 & -.228 & -4.165 & .000 \\
& Mass Media Advertising & .613 & .060 & .671 & 10.224 & .000 \\
& Promotions & .082 & .048 & .092 & 1.727 & .085 \\
& Direct Marketing & .184 & .053 & .183 & 3.475 & .001 \\
& Public Relations & .318 & .048 & .324 & 6.597 & .000 \\
& Online Marketing & -.061 & .036 & -.100 & -1.707 & .089 \\
\hline
\end{tabular}

Based on table (9) above, it can be noted that multiple regression was used to test the hypotheses, It was found that $\mathrm{R}=(0.845)$ is the correlation of the independent variables and the dependent variable. Also it was found that the $\mathrm{F}$ value of $(141.853)$ is significant at $(0.05)$ level. Thus, there is a statistically significant influence of the independent variables and the dependent variable. Also it was found that $t$ value for each dimension is significant at (0.05) level except (Online Marketing and Promotions) dimensions. So, there is a statistically significant influence of each dimension on the dependent variable except (Online Marketing and Promotions).

\section{Discussion}

According to the analysis above, and based on the hypotheses of the study, the researcher claims that IMC has a positive influence in increasing the efficiency of the internet-based marketing among customers. Based on the analysis, it appeared that there is an influence of IMC on the efficiency of the internet-based marketing from the perspective of the Jordanian customers. Through the analysis, the results varied between string influence and weak influence reaching to no influence at all of the IMC dimensions on the efficiency of the interne-based marketing. Based on that argument, it was found out that there is a statistically significant influence of public relations, direct marketing, Communicational Message, and Mass Media Advertising on the efficiency of internet-based marketing while online marketing and promotions were found to be of no statistically significant influence on the efficiency of online marketing in general. 
The results of the study indicated the most influential variable of all of the study variables appeared to be the mass media advertising followed by the public relations and direct marketing. The results indicated that the mass media like the social media websites is one of the influential factors that increase the efficiency of the internet-based marketing techniques. It has the ability to gather the targeted audience within one platform, through that way; the organizational would have the entire needed tool to contact with the customers directly as a promoting and a marketing tool and have their attention towards the product/service under examination.

Also, it was found out that the direct messaging and the communicational messaging is also important in increasing the efficiency of the intern-based marketing. Normally, the idea of direct messaging and communication is considered to be one of the CRM tools, through this tool the customer would be feeling important and it helps in increasing the level of satisfaction among the customers through the direct communication with them. The idea in itself facilitates the communication between the marketer and the customer, that way; more attention will be put on the product/service and the marketing plans would pay off.

Looking back at the analysis, it can be seen that the variables which were positive are (communicational messaging, public relations, mass media advertising and direct marketing); all of these variable require an actual dealing with the client, while promotions and online marketing do not require actual dealing with the client, and that is while the previously mentioned variable were most influential on the efficiency of the internet-based marketing.

\section{Conclusion}

The current study investigated the influence of integrated marketing communication on the efficiency of the internet-based marketing from the perspective of Jordanian customers. The study hypothesizes that IMC increases the efficiency of the internet-based marketing from the perspective of the Jordanian customer. This influence was examined through the variables of IMC including (communicational messaging, direct marketing, promotions, online marketing, Mass Media Advertising and public relations).

The results indicated that IMC does have an influence on the efficiency of internet-based marketing through the variables of (communicational messaging, direct marketing, Mass Media Advertising and public relations) while the variables of (promotions and online marketing) had no influence on the efficiency of internet-based marketing which was seen to be related to the idea that the efficiency of internet-based marketing and IMC can be gathered through the concept of direct communication with the client is the most influential variables in terms of increasing the efficiency of the internet marketing. The results of the study rhymed with what came along with (Al Khattab, Abu-Rumman, \& Zaidan, 2015) when they argued that internet marketing requires a direct communication with the customer in order to get the needed benefits of the idea itself. However, according to (Soba \& Aydin, 2013) IMC strategies help the organization to be able to understand the perception of the customer regardless of their geographical place, this enables the organization to present the service to customer and connect with them through the internet as a medium regardless of the geographical boundaries and limitations which increases the level of customer satisfaction bearing in mind that in the case of online marketing the store appears as an idea and there is real existence of it; this highly supports the fact that IMC increases the efficiency of internet-based marketing. at the same time, both Sisodia \& Telrandhe (2010) found out in their study that IMC supported all types of businesses in India which were seeking to employ internet in its operations. This concept has focused on more than one dimension in the organization which included the communication and direct messaging as a part of CRM leading to a complete circle of marketing plans and strategies through IMC.

Also, the results of the study rhymed with Hawkins, Bulmer, \& Eagle (2011) who argued that IMC practices and dimensions are mostly active within the social media platforms in which the marketing is being done through the internet and based on interacting within the social media websites. Also, the results of the study rhymed within the results of Ots \& Nyilasy (2017) who argued that IMC can be activated mostly through the communication medium of the social media in which the organization can have a direct communication line with the customers in order to guarantee the retention of the current customers and the attracting of the potential customers.

\section{Recommendations}

The following section presents the recommended point of views which are provided by the author based on the results of the study, the recommendations are as follow:

\subsection{Managerial Recommendations}

- Organizations should pay more attention in training employees of the best and most suitable approaches to deal directly with customer through the mass media platforms. 
- $\quad$ Organization should run training courses; seminars and workshops on the concept of integrated marketing communication which seeks to help employees better employ their understanding of IMC and how to understand their place in the marketing scheme.

- $\quad$ The efficiency of the online marketing plans should be read through applying IMC practices within the organization, that way, there would be an influence of the IMC on the online marketing and the promotions that might be presented by the organization.

\subsection{Theoretical Recommendations}

- $\quad$ The author recommends carrying out a research that examines the influence of IMC on the 7Ps and 5Ps of marketing.

- $\quad$ It is important to go through the concept of E-IMC and understand its role in increasing the efficiency of the marketing plans in general specially those which are done through the internet.

\section{References}

Advertising worth talking about (the relationship between advertising and word-of-mouth communication in marketing). (2011). Strategic Direction, 27(5).

Akhter, S. (1988). Direct marketing infrastructure.An indicator of direct marketing potential in foreign markets. Journal of Direct Marketing, 2(1), 13-27. https://doi.org/10.1002/dir.4000020105

Al Khattab, S., Abu-Rumman, A., \& Zaidan, G. (2015). E-Integrated Marketing Communication and Its Impact on Customers' Attitudes. American Journal of Industrial and Business Management, 5(8), 538-547. https://doi.org/10.4236/ajibm.2015.58053

Beltsville, A. (2004). Theoretical Framework Multi-Year Mass Media Campaign Plan. Food Safety and Inspection Service, 3(5).

Bird, R., \& Bird, B. (2017). Direct marketing_-The new rules. Hertfordshire Law Journal, 2(1), 3-30.

Blakeman, R. (2010). The Bare Bones: Introduction to Integrated Marketing Communication20104The Bare Bones: Introduction to Integrated Marketing Communication. Lanham, MD: Rowman \& Littlefield Publishers 2009. 305 pp. www.rowmanlittlefield.com. Journal of Consumer Marketing, 27(6), 566.

Bruhn, M., \& Schnebelen, S. (2017). Integrated marketing communication-from an instrumental to a customer-centric perspective. European Journal of Marketing, 51(3), 464-489. https://doi.org/10.1108/EJM-08-2015-0591

Burnett, J. (2012). Communicating To Mass Markets (2nd ed.).

Cowell, D. (1984). Sales Promotions and the Marketing of Local Government Recreation and Leisure Services. European Journal of Marketing, 18(2), 114-120. https://doi.org/10.1108/EUM0000000004775

Finne, Å., \& Grönroos, C. (2017). Communication-in-use: customer-integrated marketing communication. European Journal of Marketing, 51(3), 445-463. https://doi.org/10.1108/EJM-08-2015-0553

Furrer, O., \& Sudharshan, D. (2001). Internet marketing research: opportunities and problems. Qualitative Market Research: An International Journal, 4(3), 123-129. https://doi.org/10.1108/13522750110393026

Grönroos, C. (2004). The relationship marketing process: communication, interaction, dialogue, value. Journal of Business \& Industrial Marketing, 19(2), 99-113. https://doi.org/10.1108/08858620410523981

Grove, S., Carlson, L., \& Dorsch, M. (2002). Addressing services' intangibility through integrated marketing communication: an exploratory study. Journal of Services Marketing, 16(5), 393-411. https://doi.org/10.1108/08876040210436876

Gürel, E., \& Kavak, B. (2010). A conceptual model for public relations in museums. European Journal of Marketing, 44(1/2), 42-65. https://doi.org/10.1108/03090561011008600

Hamill, J. (1997). The Internet and international marketing. International Marketing Review, 14(5), $300-323$. https://doi.org/10.1108/02651339710184280

Harlow, D. (2014). An Assortment of Public Relations Definitions. Retrieved from https://www.nku.edu/ turney/prclass/readings/pr_definitions.pdf

Hauser, W. (2008). Successful Direct Marketing Methods20081Bob Stone and Ron Jacobs. Successful Direct Marketing Methods. McGraw-Hill, 2007. Direct Marketing: An International Journal, 2(1), 58-59.

Hawkins, J., Bulmer, S., \& Eagle, L. (2011). Evidence of IMC in social marketing. Journal of Social Marketing, 


\section{1(3), 228-239. https://doi.org/10.1108/20426761111170722}

Henninger, C., Alevizou, P., \& Oates, C. (2017). IMC, social media and UK fashion micro-organisations. European Journal of Marketing, 51(3), 668-691. https://doi.org/10.1108/EJM-08-2015-0599

Huang, H., Chang, Y., Yeh, C., \& Liao, C. (2014). Promote the price promotion. International Journal of Contemporary Hospitality Management, 26(7), 1065-1082. https://doi.org/10.1108/IJCHM-05-2013-0204

Khoo-Lattimore, C. (2012). Qualitative Research Methods in Public Relations and Marketing Communications 20121 Christine Daymon and Immy Holloway. Qualitative Research Methods in Public Relations and Marketing Communications. Managing Service Quality: An International Journal, 22(1), 98-100. London, and New York: Routledge.

Kitchen, P. (2005). New paradigm-IMC-under fire. Competitiveness Review, 15(1), 72-80. https://doi.org/10.1108/10595420510818713

Korgaonkar, P., Karson, E., \& Lund, D. (2000). Hispanics and direct marketing advertising. Journal of Consumer Marketing, 17(2), 137-157. https://doi.org/10.1108/07363760010317204

Littler, D. (2015). Mass Media. Wiley Encyclopedia of Management (pp.1-1). https://doi.org/10.1002/9781118785317.weom090526

Mallin, M., \& Finkle, T. (2007). Social entrepreneurship and direct marketing. Direct Marketing: An International Journal, 1(2), 68-77. https://doi.org/10.1108/17505930710756833

Naeem, B., Bilal, M., \& Naz, U. (2013). Integrated Marketing Communication: A Review Paper. Interdisciplinary Journal of Contemporary Research in Business, 5(5).

Neuhaus, C., \& Snowden, K. (2003). Public relations for a university library: a marketing programme is born. Library Management, 24(4/5), 193-203. https://doi.org/10.1108/01435120310475293

Oancea, O., \& Elena, M. (2015). The Model of Integrated Marketing Communication: Who has the Role to Influence Consumer Behaviour. ACTA Universitatis Danubius, 11(1).

Ots, M., \& Nyilasy, G. (2017). Just doing it: theorising integrated marketing communications (IMC) practices. European Journal of Marketing, 51(3), 490-510. https://doi.org/10.1108/EJM-08-2015-0595

Pitta, D., \& Fowler, D. (2005). Internet community forums: an untapped resource for consumer marketers. Journal of Consumer Marketing, 22(5), 265-274. https://doi.org/10.1108/07363760510611699

Porcu, L., Del Barrio-García, S., \& Kitchen, P. (2017). Measuring integrated marketing communication by taking a broad organisational approach. European Journal of Marketing, 51(3), 692-718. https://doi.org/10.1108/EJM-08-2015-0587

Quesinberry Stokes, A. (2009). Living the sweet (d)Life: public relations, IMC, and diabetes. Journal of Communication Management, 13(4), 343-361. https://doi.org/10.1108/13632540911004614

Saeed, R., Naeem, B., Bilal, M., \& Naz, U. (2013). Integrated Marketing Communication: A Review Paper. Interdisciplinary Journal of Contemporary Research in Business, 5(5).

Schofield, A. (1995). The definition of direct marketing: A rejoinder to bauer and miglautsch. Journal of Direct Marketing, 9(2), 32-38. https://doi.org/10.1002/dir.4000090206

Sharma, A., Singh, K., \& Sharma, A. (2015). The Emergence of E-Commerce in India: A Unique Marketing Strategy. Ckpim Business Review, 15(10).

Sheth, J., \& Sharma, A. (2005). International e - marketing: opportunities and issues. International Marketing Review, 22(6), 611-622. https://doi.org/10.1108/02651330510630249

Sisodia, S., \& Telrandhe, N. (2010). Role of Integrated Marketing Communication in Modern Indian Business. Journal of Arts Science \& Commerce, 1(1).

Sloka, B., Kantane, I., \& Vidruska, R. (2016). Decision Making On Advertising Efficiency in Internet (Results of Entrepreneurs Survey On Internet Marketing). International Conference "Economic Science for Rural Development" No 43 (p. 206). Latvia: University of Latvia.

Valos, M., Haji Habibi, F., Casidy, R., Driesener, C., \& Maplestone, V. (2016). Exploring the integration of social media within integrated marketing communication frameworks. Marketing Intelligence \& Planning, 34(1), 19-40. https://doi.org/10.1108/MIP-09-2014-0169

Wilson, A., \& Laskey, N. (2003). Internet based marketing research: a serious alternative to traditional research 
methods?. Marketing Intelligence \& Planning, 21(2), 79-84. https://doi.org/10.1108/02634500310465380

Winter, S. and Sundqvist, S. (2009). IMC strategies in new high technology product launches. Marketing Intelligence \& Planning, 27(2), 191-215. https://doi.org/10.1108/02634500910944986

Yurovskiy, V. (2014). Pros and Cons of Internet Marketing. Retrieved from http://www.turiba.lv/f/StudZinKonf_Yurovskiy.pdf

\section{Copyrights}

Copyright for this article is retained by the author, with first publication rights granted to the journal.

This is an open-access article distributed under the terms and conditions of the Creative Commons Attribution license (http://creativecommons.org/licenses/by/4.0/). 